\title{
INDIGENOUS AMAZONIA AND DECOLONIZING SOCIAL WORK
}

BY KEPA FERNÁNDEZ DE LARRINOA

\section{ABSTRACT}

This article reflects on the need of an indigenous social work practice committed to the social, cultural, political and economic conditions of the Ecuadorian Amazon region. In case of projecting in the University system an indigenous social work training program for the peoples of the Amazon rainforest, it should promote community social action as well as being supported by key leading ideas, such as: ecological and environmental justice; cultural expertise; restorative spirituality; and political awareness of colonial and postcolonial experience of the local history. This article claims that three principles must be discussed in depth in order to prepare a university curriculum concerning indigenous social work in the Amazon region of Ecuador: one is the concept of cultural competence; another, the notion of indigenization of social work; and third, what is understood in indigenous social work by decolonizing social intervention methodologies and techniques. 


\section{INTRODUCTION}

This chapter concerns social work among Amazon indigenous peoples. It portrays a framework with which to discuss the notion of indigenous social work embedded in communities in the Amazonian rainforests. It is argued that a shift of focus is needed within the field of social work; from the currently overall and overlapping notion of social work in indigenous communities to one rooted in native constructs of the social self. Such a framework can point at a model, which I suggest to designate as indigenous social work in indigenously understood societies.

In order to support such a change, several concerns need attention. The first consists of examining the later social policies of the Ecuadorian government in the Amazon region. During the 2000's and onwards, a nationwide social policy decidedly impregnated with a conspicuous cultural patina, has been implemented. In addition, there is a need to consider the Ecuadorian indigenous social movement strength, both in terms of group organization and political influence on national and local governments. In this chapter, I ask the following questions; is there an indigenous reasoning embedded in the Amazonian communities? If so, how should a university program of indigenous social work in the Amazon region be organized? In addition, I ask how to exercise it in the social praxis characteristic of the contemporary rainforest?

This article departs from two interconnected political debates that circulate around social work. One is the assertion that social work is a historically determined Western social device to solve Western-rooted social issues. The other focuses on social work in indigenous communities, and to what extent social work pursues just sociocultural adjustments to political processes of westernization. Thus, when indigenous social work is understood as ideological decolonization from western conceptions of the individual, nature and culture; then social workers frame their praxis in terms of re-appropriation.

\section{INDIGENOUS SOCIAL WORK}

In the following, I will present a framework with which to reflect on the need for an indigenous social work that is committed to the social, cultural, political and economic conditions of the Ecuadorian Amazon region. Research carried 
on this issue makes us conclude that, in the case of projecting a university curriculum pushing forward an Amazon-oriented indigenous social work system, it should promote community social action as well as being supported by key leading ideas, such as: ecological and environmental justice; cultural expertise; restorative spirituality; and political awareness of colonial and postcolonial experience of the local history. In other words, three principles must be discussed in order to prepare a university curriculum proposal on indigenous social work in the Amazon region of Ecuador. One is the concept of cultural competence; another, the notion of indigenization of social work; and third, what is understood in indigenous social work by decolonizing social intervention methodologies.

The arguments that follow are inserted in the milieu of university-taught social work and in everyday social work practice in indigenous sociocultural environments. I depart by focusing on proposals claimed for indigenous social work that have been formulated by indigenous lecturers and researchers who are assigned to Social Work or Indigenous Studies departments at universities in Anglo-Saxon and Scandinavian countries. In the field of social work, there is an increasing literature on decolonization. This is particularly true in the case of indigenous social work in Anglo-Saxon and Arctic Scandinavian colonial settlements where international networks of collaboration, debate, thought and common action are important. These networks involve indigenous academics and social work professionals committed to a renewal of indigenous approaches to social knowledge, including its application to indigenous social, community and political action.

While the bulk of the work of bringing forth and centering Indigenous knowledge and practices into social work rests, rightfully, with indigenous people, it is clear that settler societies also have work to do. This work is ideally anti-colonial and decolonizing, and involves settler societies working collaboratively with indigenous people to challenge the boundaries implicit in colonial mindsets (Hart \& Burton, 2016, p.4-5).

These countries have lately debated social work teaching and professional practice, relating to scenarios of social intervention in indigenous communities. No doubt the notion of "indigenous research paradigm and knowledge methodologies" has been a key issue. Within this approach, there is a call to 
reformulate western epistemologies by adopting decolonizing and emancipating frameworks to and for human knowledge and interpretations of the world. Decolonizing theoretical and methodological proposals within social work are sustained in the following observation: the notions of indigenous, native and aboriginal have been forged in combinations of geographic spaces and historical times precisely linked to situations of overseas coloniality. However, the epitome of social work is embedded in a rather western process of modernization and industrialization.

Significantly, decolonizing theoretical and methodological approaches to social work underline that both the Euro-American modernization process and the colonial geography of marginality are co-dependent. Western and later on Westernized makings of modern and industrialized nations, and the worldwide spreading out of indigenous colonialities, are not but a progression of reciprocal feedbacks, i.e., a conjointly operating political-economic process. As Colombian scholar, Arturo Escobar explained years ago, Euro-American modernity, economic development and third world underdevelopment and poverty are the two sides of the very same coin: the emergency of capital economies and capitalism expansion over the globe (Escobar, 1995).

Social identity categories as 'Indian', 'native' and 'aboriginal' came to birth in situations of political and economic coloniality. Social work, however, emerged inside processes of Western national modernization. Therefore, when we analyze the colonial praxis vis à vis the rhetoric of modernity, we discover that Indian, native and aboriginal are categories that emerged in situations of domination, i.e., in situations in which the dominant metropolis projected ethno-racial criteria of classification upon dominated local populations. As a result, "indigenous identity" becomes synonymous with "subaltern identity". Hence, the importance given in indigenous social work to theorizing about intervention schemes and cultural action experiences oriented toward the decolonization of mind, thought and social life (Ashcroft, Griffiths, \& Tiffin, 1995; Mezzadra, 2008; Gray, Coates, Yellow Bird, \& Hetherington, 2013).

Many authors have analyzed the issue of colonial praxis vis à vis the rhetoric of modernity in Latin America. They have shown that "indigenous" is an expression by means of which relations of political, economic and cultural control and authority are imposed. Consequently, it has been argued that contemporary indigenous identities must be seen and studied as subaltern iden- 
tities (Bonfil, 1987; Quijano, 2000; Mignolo, 2007). As this subalternity is deeply rooted in national and international policies of economic growth and profit maximization largely based on the exploitation of natural resources, the conclusion can be drawn that indigenous social work ought to come to the fore attached to philosophies of thought-decolonization, as well as promoting social practices directed at cultural emancipation.

\section{CULTURAL CRITICISM OF SOCIAL WORK}

According to what I have disclosed above, in this section I address social work expertise in the context of indigenous societies and populations. To this end, I distinguish two regions of inquiry. One is related to the practice of social work in indigenous communities. The other is connected to the creation and transmission of social work knowledge in research and higher education centres. On the whole, I discuss several understandings of indigenous social work. However, my focus is on a specific understanding recently formulated by indigenous teachers and researchers assigned to social work departments in universities of affluent Anglo-Saxon countries with a native population in their midst.

Elsewhere I have addressed the study of Western notions of epistemology and research methodologies inside indigenous social work in English-speaking university education and effectiveness-oriented job performance (Fernandez de Larrinoa, 2016). By so doing, I intend two things: first, to put a distinctive emphasis on the departing point in this chapter; and second, to draw a theoretical picture wherein we could subsequently discuss shared bonds and disconnections between Anglo-Saxon and Latin American indigenous peoples' experiences in social action, in particular those of the Amazonian rainforest. Academics such as Smith (1999); Gray, Coates, \& Yellow Bird (2008); Gray et. al. (2013); and Hart \& Burton (2016), underlined that social work with indigenous communities must be carried out in terms of human rights and cultural empowerment. To be more precise, they have promoted examinations of social work by means of which it becomes fully discernible that a clear-cut political dimension accompanies the learning and praxis of social work, most noteworthy in the context of indigenous peoples, communities and societies. 


\section{A CULTURAL CRITIQUE OF SOCIAL WORK}

Social work has become internationalized and globalized: from European and North American cities, neighbourhoods to rural towns, then travelled to the countries of the South, and now fully enters indigenous communities. Gray, Coates \& Yellow Bird (2008) ask if social work is a western invention linked to the central ideas of nation-States, such as, the idea of modernity and individualism; a productivity-industrial economy; and the social caring political ethics attached to democratic-Christian and social-democratic parliamentary parties? They argue that the internationalization of academic social work, in addition to the globalization of its practice, are not but effects of late-modernity and late-capitalism.

The global economic expansion of our times has been accompanied by another expansion, that of social work. This internationalization of social work, establishing itself in countries of the South, entails the danger of imperialism resulting in professional colonization. One can put it this way: like many other modern Western professions, social work has been incorporated into the memorandum of globalization, uncritically agreeing with a unifying and universalizing view of social and cultural life, one which inspires to implement social interventions of the same kind, even in unmistakably dissimilar cultural situations and contexts (Midgley, 1981).

Challenging the view, Gray Coates and Yellow Bird, (2008) call for a form of social work that has to be consistent with the local society and culture.

The real issue with which we are dealing with is the development of culturally relevant social work practice and education around the world [...] Claims to 'global' and 'universal' social work present to paradox for those concerned with social work's responsiveness to local cultural contexts $[\ldots]$ Most who are involved in international social work are mainly concerned with developing models of culturally relevant social work practice in local contexts, among cultures with varying degrees of difference from their own [...]. Thus we believe that claims to 'global' social work are not only an exaggeration of the reach of social work but also deny the importance of nongovernment organizations, community and social development which play a greater role in working with the majority of the world's population who are in need (Gray, Coates and Yellow Bird, 2008, p.25). 


\section{INDIGENOUS CULTURAL SYSTEMS AND SOCIAL WORK}

Most indigenous peoples live in ecosystems sui generis with languages and cultures that are embedded in the land. Worldwide human worries such as global warming and climate change have provided native peoples with the position, as guardians, of endangered environments as well as stewards of scarce natural resources. In consequence, new expressions have been coined, e.g., "ecosocial work" (Molyneaux, 2010; Coates \& Gray, 2012). Even so, indigenous cultural frameworks and social life interpretive systems are still subjects of controversy and discussion among scientists (Peat, 2012; Hendry, 2014). Weaver (1999) argue that; "I have not been able to identify any empirical work on cultural competence with Native Americans" (Weaver, 1999, p.218). Another argues that;

The reconciliation of social work theory and practices with Indigenous peoples of Canada is currently in critical dialogue due to the social work profession's historic and ongoing contribution to colonization [...). Although some footing has been made through innovative, Indigenous centered curriculum and university safe spaces where social work is transmitted to next generation of students, contributions in the field education remain scarce. (Clark, Reid, Valley, Drolet, Walton, Peirce, Charles, Vedan, Samuel, Matyhews, Bruke, \& Arnouse, 2012, p. 115-116).

With regard to the meaning ascribed to cultural competence in social work, native scholars have observed outstanding deficiencies even during the last decades. However, it would be unfair to conclude the inexistence of indigenous social work experiences based on indigenous cultural conceptions, carried out by indigenous social workers. On the contrary, as Munford \& Sanders (2010) argue from the position of Maori social workers: "Of particular importance for Maori, and central to achieving wellbeing, is the connection with one's ancestry and a foregrounding of cultural meaning systems, including spirituality" (Munford \& Sanders 2010, p.3).

The commitment of social and community workers in New Zealand to embrace new ways of working and to be challenged by alternative frameworks is part of a search for models that can more effectively 
support families and communities [...]. A notable example of this is Te Whare Tapu Wha model [...] Frameworks of practice such as this are now used widely and Maori understandings of social and health experiences increasingly inform the approach to practice of state and non-government agencies (NGOs) (Munford \& Sanders, 2010, p.3).

\section{INDIGENOUS RESEARCH PARADIGM}

The examples given above illustrate the fragility of indigenous cultural systems, epistemologies and methodologies in the building of social work university knowledge. We should distinguish between these two separate terminologies: on the one hand, culturally competent or sensitive social work; and, on the other, radical indigenous social work. The former - as explained above - reflects on fragmented and disconnected assimilations of one or several cultural fundamentals attributed to given indigenous systems of sociability and knowledge of social work practice and job education. The latter means something quite different: the process of thinking of, training in, and carrying out social work in the context of indigenous peoples from their perspectives and methodologies.

Things are changing in the realm of research. While at one time, we, as Indigenous peoples, were faced with leaving our indigenity at the door when we entered the academic world, several of us are actively working to ensure our research is not only respectful or 'culturally sensitive', but is also based on approaches and processes that are parts of our cultures (Hart, 2010, p.1).

In the best of cases, indigenous interpretations of mutual aid might be incorporated into social work knowledge and interpretation, by following a politically correct rhetoric of respect and tolerance of cultural difference. When this happens, cultural sensitivity and competence consists of selecting the indigenous cultural pieces that best fit Western scientific knowledge.

In contrast, Hart (2008) defends the existence of a specifically indigenous research paradigm outside Western conceptions of scientific knowledge. Notwithstanding the ideal of universality that governs Western scientific thought, disparity - if not contradiction - prevails within it. Similarly, there is dispar- 
ity and inconsistency within indigenous worldviews and cosmologies (Parkin, 1982). However, group sociability inside indigenous societies is culturally constructed upon a common principle: relational reciprocity.

Indigenous knowledge conveys a particular research paradigm linked onto an ontology, which indigenous peoples conceptualize in relation to domains of spiritual relationships, which at the same time are connected with domains of relationships. Both domains materialize themselves and interact, one with the other, by following patterns of reciprocity ordered and structured in the course of ritual ceremony. Second, there is an epistemology that reflects an indigenous thought system with its own logic of knowledge production and reproduction, where creation, experimentation, and transmission are collective processes. Third is the methodology, which rests on the idea of reciprocity of life implying a relational and collective accountability. Namely, knowledge acquired within systems of reciprocity between humans, spirits, and physical objects established in rituals and ceremonies, is prearranged to be of practical application in community relationships. Finally, indigenous research paradigms bear an all-encompassing ethical dimension. Since indigenous knowledge is tied up with community making. Research methods are intended to benefit the community. Ethics in the indigenous research paradigm is not but the subjective recognition of the creative process of the person who creates knowledge and transmits it in a collective context (Hart, 2010).

\section{TOWARD AN INDIGENOUS SOCIAL MOVEMENT}

Is there any model of indigenous research action that is specifically indigenous in Latin American social work practice? I will attend to this question, by a discussion of the relation between social work, society and culture in Ecuador, followed by reflecting upon ethnic and cultural difference in social policy in the Amazon basin. Hence, I address hereafter the concept of cultural competence, the notion of indigenization of social work, and the idea of decolonizing social intervention methodologies as they have developed in the context of Latin American social work and social work policy.

Latin American social work of the $21^{\text {st }}$ century calls for models of professional practice and university education allied with social justice-oriented scientific research, knowledge transmission and job instruction (Cifuentes, 2013). Since its first formal establishment in Chile in 1925, Latin American 
social workers have been generally trained in schools, centres, and departments attached to universities, that have learning routes that shift according to country, type of government, and lapse of time. Nevertheless, social work has been characterized by its commitment to social change and the transformation of society.

When examining change induced by social workers, it is important to be aware of the kind of change they are specifically pointing to. Namely, they should think of the how and why of the change that is aimed at. Hence, the question: has any specific model of indigenous research paradigm entered Latin American social work? What is striking in the recent history of Latin America is the strength, both political and social, with which in the late 1990s and early 2000s indigenous movements forced national governments and international institutions to recognize them as citizens who carry rights of their own.

Latin American indigenous knowledge systems, languages, and interpretations of social reality, along with indigenous models of sociability and human interaction with the ecosystem, have captured national and international political attention. Do these most recent indigenous social movements contribute to reformulate spaces, times and processes of creation and dissemination of university knowledge? Is it reflected in the organization and conceptualization of the teaching and job practice of social work with and/or for the native populations of Latin America?

It is a challenge for Social Work to question the hegemony of those who sustain their knowledge in criteria of validity that are established by and for themselves; a challenge that increases if we take into account that in general the profession is formed and exercised in two key spaces of hegemony of modern forms of rationality: the university and the State (Gómez Lechaptois, 2014, p.92).

The question remains unanswered; does social work act upon knowledge structures and methods concerning indigenous research paradigms and thought systems? In the search for answers, we must look at three realms: Latin American social work history and current training; current Latin American indigenously rooted social movements; and social policy and social work performance in the Amazon vis á vis nationwide discourses of welfare and wellbeing. 


\section{CONCEPTUALIZING SOCIAL WORK}

In the 1960s and 1970s, Latin American social work took a rebellious and subversive course. Until then, social work was operating according to the charity-welfare, aseptic-technocratic, developmentalist and integrative models imported from Europe and America (Ponce, Malvina, \& Paiva Zuaznábar, 2001) and was subordinated to developmental projects linked to North American political economic interests (Smith, 1999). In the 1960s and 1970s a breakthrough materialized in social work in Latin America. This happened in accordance with an ideal of solving human misery by transforming social order (Quezada Villegas, 2001). To change socioeconomic structures, social work intellectually censured the national and international, political and economic causes that generated poverty in Latin America. This, however, in praxis advocated both social commitment and politically active collective participation. Reconceptualization of social work was the expression that broke the rupturist current (Ander-Egg, 1984).

Reconceptualized social work puts the emphasis on social activism and collective learning through practical social action framed in social mobilization. Reconceptualized social work aspires to redeem Latin American society from its social, cultural, economic and political history of exploitation and external dependence. Transformative social action presents an interpretation of social intervention based on the identification of class interests (Navas, 1990). Reconceptualized social work proposed to operate by means of collective social work workshops (Quezada Venegas, 2001). It was understood as being based on participatory action research (Fals et al., 1986). Remarkably, this was a strategy of and for collective social intervention conceived both to create shared knowledge and to complete collective and participatory analysis of social reality. Presented in public at the end of 1969 in a Latin American congress, this philosophy of liberation arrived as a prelude to present-time postcolonial studies of subalternity and decolonization:

Globally it [philosophy of liberation] is the emergence in the periphery of a critical thought that will develop up to the present. It is about the awareness of reality in the peripheral world, on the horizon of the countries that were colonies of Europe, where sciences in general, and social sciences and philosophy in particular, also had a colonial character, repetition of the categorical and methodical horizon of the metropolitan sciences [...]. 
The philosophy of liberation is then the first philosophical movement that begins the epistemological decolonization of philosophy itself, from the world periphery, criticizing the claim of universality of European and North American modern thought located at the center of the world-system. At the time of its birth, neither its creators nor its critics were aware of this global meaning, which makes more sense than ever at the beginning of the $21^{\text {st }}$ century (Solis, Ortiz, Zuniga, Galindo \& González Melchor, 2009, p.399-400).

In short, the reconceptualization of social work consisted of a Latin-Americanization of social action. It happened in the 1960s and 1970s. It deployed a revolutionary banner attached to a well-felt goal on the continent, liberation, which in the context of that time sank its roots in a specific philosophy. This philosophy received ideas from social Christianity, humanist socialism, and cultural memories and imaginaries of the pre-Columbian mythical world.

\section{SUMAK KAWSAY AND WELFARE STATE IN LATIN AMERICA}

A conspicuous topic in Latin America during the $21^{\text {st }}$ century has been the progressive indigenous protagonism in the political, cultural and economic life of the States in which they reside. As social movements that bring together marginal and oppressed ethnic groups, they have constructed a particular view of how to understand social policy and cultural difference within Latin American nation-States (González Piñeres, 2004). This has been especially true in the Andean region, and prominence must be given to the indigenous political organizations of Bolivia and Ecuador whose dynamism has put indigenous men and women in politically meaningful government posts. A consequence of the Bolivian and Ecuadorian indigenous later social movements has been the shaping of a way of thinking about social policy and State-designed social intervention that sharply contrasts previous Latin American perspectives on induced social change (Gudynas, Guevara, \& Roque, 2008). Such a way of thinking social policy and intervention is known in the Quichua language with names as Sumak Kawsay, or Sumak Kuasi [Good Living] (Huanacuni, 2010). 
Sumak Kawsay and its Spanish translation, Buen Vivir, are fashionable expressions in current Latin American Social Policy Studies (Fatheuer, 2011). The latest significance of this notion for social policy planers and human development researchers rests on several circumstances. Particularly important is that Sumak Kawsay has not entered the domain of parliamentary speech, academic dissertation and domestic law regulations in Latin America out of the blue. On the contrary, the actuality of its present-day strength is a consequence of a variety of social, political and cultural forces. A point to be emphasized is that Sumak Kawsay is a peasant Andean notion whose conceptual transference to the Spanish-speaking world stems from radical political activism carried out by indigenous organizations and social movements in Bolivia and Ecuador since the 1980's onwards (Schavelzon, 2015). Therefore, not only is Sumak Kawsay a foreign expression, but also a foreign concept in Western and Westernized societies.

In regard to the argument in this essay, suffice it to say that Sumak Kawsay is an expression selected from peasant Andean culture in order to advance social welfare policies in Latin American society based on a non-Western understanding of human wellbeing and progress (Acosta \& Martínez, 2014). Hence, Sumak Kawsay has moved in from its original peasant Andean community-bounded realm of social relationships, to the much wider pan-Hispanic sphere of social policy planning and thinking. Moreover, being an indigenous proposal for collective social change, Sumak Kawsay reflects a cultural interpretation of an ideal of people's welfare that contrasts sharply with the ideas and attitudes hitherto sustained by university lecturers and professional social workers and by State politicians and civil servants. For instance, the notion of Sumak Kawsay gave to Ecuador a new Constitution that acknowledged the "rights of the nature" (Gudynas, 2009).

However, further than the Rousseaunian exotics of primitivism and the politically interested discursive recognition of the expression, the indigenous peoples of Ecuador have felt that Sumak Kawsay faces strong opposition to the concept's practical implementation in indigenous communities and elsewhere. This is particularly manifest in the period 2007-2009 and beyond when President of the Republic Rafael Correa and CONAIE (Confederation of Indigenous Nationalities of Ecuador) stopped collaborating with each other and started a political pulse and mutual conflict still in force (Resina de la Fuente, 2012). As said above, Sumak Kawsay [Good Living] is a conception 
of human and social well-being that originated in the bosom of Latin American popular culture of the Andean region. Rooted in the indigenous peasant worldview of Ecuador and Bolivia, it came to public knowledge and collective demand throughout the political struggle. In particular, in Ecuador it is Pachakutic who better represents indigenous claims for self-determination and genuine ethnic interculturality and State plurinationality. In this sense, Pachakutic has been an indigenous political organization calling for factual changes in cultural and social policy regarding the social and cultural needs expressed from within indigenous communities (Becker, 2015). Now the question arises: How does Ecuadorian present-time social work connect with the proposals of Sumak Kawsay and Interculturality that reach the spaces of political decision and public relations through indigenous political wrestling with the State?

Several reasons support the relevance of this question. First is that Ecuador includes indigenous rights in the Constitution of 2008 (Walsh 2010; Martínez, 2009). Second is that the later Ecuadorian government has betrayed the indigenous worldviews previously accepted as central in national politics, after having appropriated them discursively (Walsh, 2010; Domínguez \& Caria, 2014). Third is that such institutional appropriation is subject to contestation on the part of the leaders and activists of the social movements, mostly on the part of indigenous organizations and community representatives (Resina de la Fuente, 2012). Fourth is that there are intellectuals, academics, university professors and non-university teachers who contest either the politically appropriation of indigenous knowledge and cosmologies or their institutional rejection (Walsh, 2012). Finally, there are those who disapprove of the inclusion of indigenous knowledge and cosmologies in the national charter of citizens' rights, and persist against their governmental implementation because they profess ideas still embedded in historical-cultural structures of racist and colonial thought (Gros, 2000; Zambrano, 2002).

\section{A FUTURISTIC INDIGENOUS SOCIAL WORK IN AMAZONIA SOCIETY?}

I have pointed out the emergence in Latin America in the 1960s and 1970s as a way of thinking about social work in which two situations became interweaved. One was an ideal economic growth following from development policies toward industrialization and technology-based agriculture and livestock production. Another was the rise of socialist and communist societies as a 
political guarantee of individual and collective social justice. The result of that conjunction was a conceptualization of social work linked to Karl Marx's critique of capital: social classes immersed in an antagonistic structural conflict, concluding with an upcoming revolutionary social change. On the other hand, perspectives such as Sumak Kawsay invite us to think about social work from another point or view, that of the rural-peasant and Andean highlander of Ecuador and Bolivia, which runs tête a tête with ongoing neoliberal liberal schemes of local development, mainly based on mineral, gas, oil, and timber extraction. As a rule, neoliberal understandings of social work are directed to efficiency management thought: to obtain maximum material benefit on a minimum economic cost. In sharp contrast, indigenous social work at the present time in opulent countries instead is connected to community healing from colonial cultural stress through narrative (Fitznor, 2012), ceremony (Wilson, 2009) and cultural heritage repatriation (Peers, Reinius, \& Shannon, 2017).

In Latin America Sumak Kawsay, not without controversy, difficulties and opposition, outlines a high mountain Andean model of indigenous sociability and relationships with nature and the local peasant ecosystem, a kind of knowledge that indigenous peoples of Ecuador tried to formally establish in the so called Amawtay Wasy Indigenous University [Home of Knowledge], which CONAIE (Confederation of Indigenous Nationalities of Ecuador) organized in order to develop indigenous research and methods paradigms, not in academic campus, but in the indigenous communities where indigenous social life and indigenous knowledge is created and transmitted. However, the President of Ecuador Rafael Correa reformed university policies in Ecuador and this, being grounded in Western notions of university excellence, led him to decide to close Amawtay Wasy Indigenous University (Davalos, 2013).

Finally, lowland Amazon ecosystems vary from Andean landscapes. Whereas Bolivian and Ecuadorian indigenous ecosystems are of peasants' design, Amazon rainforests are home to small populations of hunters and gatherers. Is there any formal social work approach to Amazonian hunters and gatherers from policymakers, university lecturers, and in situ social workers that could be related to cultural competence, decolonizing social intervention, and indigenous research and methods paradigms? My examination of the matter in the field tells me that there is no such a formal attitude from either the public administration or university instruction. 
In the 1960's and 1970's, a reformulation of social work took place in Latin America. It developed within the framework of a philosophy of liberation of the oppressed popular classes. Today, this is felt in the Amazon region by the lack of a serious debate on how to understand social work from within the cultural history of colonization and the domination of the indigenous peoples of the rainforest, first by foreign Spaniard conquerors, afterwards by native nationals who happened to became Spaniardized, and lately by the global rulers of the economics of extractivism. 


\section{LITERATURE}

Acosta, A. \& Martínez, E. (2014). Desarrollo, postcrecimiento y Buen Vivir: debates e interrogantes. Abya-Yala: Quito.

Ander-Egg, E. (1984). El desafio de la reconceptualización, Humanitas: Buenos Aires.

Ashcroft, B., Griffiths, G., \& Tiffin, H. (Eds.). (1995). The postcolonial studies reader. London: Routledge.

Becker, M. (2015).;Pachakutik! Movimientos indigenas, proyectos politicos y disputas electorales en Ecuador. Abya-Yala: Quito.

Bonfil, G. (1987). México profundo, una civilización negada. Grijalbo, México D.C.

Cifuentes P., \& Rocío, M. (2013). Formación en trabajo social e investigación: una relación insoslayable de cara al siglo XXI. (p. 165-182) Revista Trabajo Social, 15.

Clark, N., Reid, M., Valley, N., Drolet, J., Walton, P., Peirce, J., Charles, G., Vedan, R., Samuel, M., Matyhews, N., Burke, S., \& Arnouse, M. (2012). Indigenous social work field education: Melq'ilwiye' coming together towards reconciliation. Native Social Work Journal (8), 105-127. https://pdfs. semanticscholar.org/c7cc/1607d386762638783c8c878032fef448f42a.pdf

Coates, J., \& Gray, M. (2012). The environment and social work: an overview and introduction. In International Journal of Social Welfare, 21(3), 230-238. https://doi.org/10.1111/j.1468-2397.2011.00851.x

Davalos, P. (2013). Apuntes sobre la colonialidad y deconolinalidad del saber: a propósito de las reformas universitarias en Ecuador. (p. 1-5) Rebelión.

Domínguez, R., \& Caria, S. (2014). La ideología del Buen Vivir: a metamorfosis de una "alternativa al desarrollo" en desarrollo de toda la vida. (p. 1-52) PreTextos para el Debate, Universidad Andina Simón Bolivar 2.

Escobar, A. (1995). Encountering development: the making and unmaking of the Third World. Princeton University Press.

Fals, B. et al. (1986). Investigación acción participativa en Colombia. Bogotá: Punta de Lanza y Foro Nacional por Colombia.

Fatheuer, T. (2011). Buen Vivir: a brief introduction to Latin America's new concepts for the good life and the rights of nature. The Green Political Foundation Heinrich Böll Stiftung.

Fitznor, L. (2012). Indigenous scholars and writing through narratives and storying for healing and bridging. In J. Hendry \& L. Firznor (Eds.), Anthropologists, Indigenous scholars and the research endeavor: seeking bridges towards mutual respect. (p. 270-283). Routledge. 
González, P \& Nidia, C. (2004). El movimiento indígena y sus paradigmas de interpretación Revista científica. Guillermo de Ockham 2,139-161.

Gray, M., Coates, J., Yellow Bird, M. (2008). Indigenous social work around the world: towards culturally relevant education and practice. Aldershot: Ashgate.

Gray M., Coates, J., Yellow Bird, M., \& Hetherington, T. (2013). Decolonizing social work. Burlington: Ashgate.

Gros, C. (2000). Politicas de la etnicidad: identidad, estado y modernidad, Instituto Colombiano de Antropología e Historia: Bogotá.

Gudynas, E., Guevara, G.,\& Roque, F. (2008). Heterodoxos. Tensiones y posibilidades de las politicas sociales de los gobiernos progresistas de América del Sur. CLAES D3E and Oxfam: Montevideo.

Gudynas, E. (2009). El mandato ecológico: derechos de la naturaleza y políticas ambientales en la nueva Constitución. Abya-Yala: Quito.

Hart, M. A. (2008). Critical reflections on an aboriginal approach to helping. In M. Gray, J. Coates \& M. Yellow Bird (Eds.). Indigenous social work around the world: towards culturally relevant education and practice. (pp. 129-139). Aldershot: Ashgate.

Hart, M. A. (2010). Indigenous worldviews, knowledges, and research: the development of an indigenous research paradigm. Journal of Indigenous Voices in Social Work, 1(1), 16.

Hart, M. A. \& Burton, A.D. (2016). Introduction. In M. A. Hart, A. D. Burton, K. Hart, G. Rowe, D. Halonen \& Y. Pompana (Eds.), International Indigenous Voices in Social Work. (p. 1-13). Newcastle upon Tyne, England: Cambridge Scholars Publishing.

Hendry, J. (2014). Science and sustainability: learning from Indigenous wisdom. New York: Palgrave Macmillan. Palgrave.

Huanacuni, M. F. (2010). Buen Vivir/Vivir Bien. Filosofía, politicas, estrategias y experiencias regionales andinas. Coordinadora Andina de Organizaciones Indígenas. CAOI.

Malagón, É. B., Leal, G. \& Gloria, E. (2006). Historia del trabajo social latinoamericano. Estado del arte. Trabajo Social. (p. 45-61). Facultad de Ciencias Humanas: Universidad Nacional de Colombia 8.

Martínez, E. (2009). Los derechos de la Naturaleza en los países amazónicos. In Derechos de la Naturaleza. El future es ahora. Abya-Yala.

Midgley, J. (1981). Professional imperialism: social work in the Third World. London: Heinemann. 
Mignolo, W. (2007). Coloniality of power and de-colonial thinking. Cultural Studies 21, 155-167. https://doi.org/10.1080/09502380601162498

Morrissette, V., McKenzie, B., \& Morrissette, L. (1993). Towards an aboriginal model of social work practice: cultural knowledge and traditional practices. Canadian Social Work Review, 10(1), 91-108. https://doi.org/10.1007/BF00757435

Munford, R. \& Sanders, J. (2010). Embracing the diversity of practice: indigenous knowledge and mainstream social work practice. Journal of Social Work Practice, 25(1), 63-77. https://doi.org/10.1080/02650533.2010.532867

Molyneaux, R. (2010). The practical realities of ecosocial work: a review of the literature. Critical Social Work, 11(2), 1-8.

Navas T. G. (1990). Iniciación al trabajo social. Universidad Central de Ecuador, Quito.

Parkin, D. (1982). Semantic anthropology. Academic Press.

Peat, F. D. (2012). Traditional knowledge and Western science. In J. Hendry \& F. Laara (Eds.). Anthropologists, Indigenous scholars and the research endeavor: seeking bridges towards mutual respect. (p. 118-127). Routledge.

Peers, L., Reinius, L.G. \& Shannon, J. (2017). Ritual repatriation. In Museum Worlds. Advances in Research 5, 1-8. https://doi.org/10.3167/armw.2017.050102

Ponce, L., Malvina, N. \& Paiva Zuaznábar, Z.D. (2001). Funcionalismo. Quesada Venegas, Margarita, et al. Perspectivas metodológicas en trabajo social. Espacio Editorial, Buenos Aires, (p. 121-150) (ALAETS-CELATS www.ts.ucr.ac.cr). Quezada Venegas, M. (2001). El contexto social de los 70. En Quesada Venegas, Margarita, et al. Perspectivas metodológicas en trabajo social. Espacio Editorial, Buenos Aires, (p. 7-20) (ALAETS-CELATS www.ts.ucr.ac.cr).

Quijano, A. (2000). Colonialidad del poder y clasificación social. Journal of World System Research, 6(IV), 342-386. http://www.ram-wan.net/restrepo/ poscolonial/9.2.colonialidad\%20del\%20poder\%20y\%20clasificacion\%20socialquijano.pdf https://doi.org/10.5195/jwsr.2000.228

Resina de la Fuente, J. (2012). La plurinacionalidad en disputa: el pulso entre Correa y la Conaie. Abya-Yala: Quito.

Schavelzon, S. (2015). Plurinacionalidad y Vivir Bien / Buen Vivir: dos conceptos leidos desde Bolivia y Ecuador post-constituyentes. Abya-Yala: Quito. 
Smith, L. T. (1999). Decolonizing methodologies: research and indigenous peoples. London: Zed Books.

Solis, N.L., Ortiz, J., Zuniga, J., Galindo, M.S., \& González Melchor, M.A. (2009). In E. Dussel, E. Mendieta \& C. Bohórquez (eds.). El pensamiento filosófico latinoamericano, del Caribe y "latino" (1300-2000). Historia, corrientes, temas y filósofos. México: CREFAL-Siglo XXI, 2009, (p. 399-417)

Walsh, C. (2010). Development as Buen Vivir: institutional arrangements and (de) colonial entanglement. Development, 53(1), 15-21. https://doi.org/10.1057/dev.2009.93

Walsh, C. (2012). Interculturalidad crítica y (de)colonialidad. Abya-Yala, Quito.

Weaver, H. N. (1999). Indigenous people and the social work profession: defining culturally competent services. Social Work, 44(3), 217-225. https://doi.org/10.1093/sw/44.3.217

Wilson, S. (2009). Research is ceremony: indigenous research methods. Halifax, N.S: Fernwood Publishing 